\title{
35. TECTONICS AND SEDIMENTATION IN THE PANAMA BASIN: GEOLOGIC RESULTS OF LEG 16, DEEP SEA DRILLING PROJECT
}

\author{
G. Ross Heath and Tjeerd H. van Andel, School of Oceanography, Oregon State University, Corvallis, Oregon
}

\begin{abstract}
DSDP Sites 155,157 , and 158 of Leg 16, and Site 84 of Leg 9 have broadly defined the depositional history of the Panama Basin and provided constraints as to its tectonic evolution. Only during the last $5 \mathrm{~m} . \mathrm{y}$. have the depositional histories of DSDP 157,84 , and 158 (the continuously cored sites) diverged strongly. DSDP 157 contains a fairly uniform sequence of carbonate-rich oozes and chalks, whereas the upper sections of DSDP 84 and 158 become progressively richer in volcanic and terrigenous debris and 158 shows a decrease in sedimentation rate from the late Miocene until the late Quaternary. These changes apparently resulted from separation of the sites due to spreading along the Galapagos Rift Zone; movement of DSDP 84 and 158 out of the productive zone along the northern fringe of the Peru Current; influx of hemipelagic sediments as the northern sites approached Central America; influx of volcanic debris to DSDP 84 from the active Coiba Fracture Zone; and a general rise in the lysocline during the late Cenozoic coupled with the normal rise of this feature along a continental margin. The basalts cored at the Leg 16 sites are more fractionated than mid-ocean ridge tholeiites, suggesting that they are derived from a "hot spot," such as the Galapagos. The depositional histories, basement compositions, and basement ages of the DSDP sites suggest that the aseismic ridges of the Panama Basin formed from the Galapagos volcanic center and the Basin itself developed by spreading along a formerly more extensive Galapagos Rift Zone during the past 15 million years.
\end{abstract}

\section{INTRODUCTION}

The Panama Basin, in the easternmost equatorial Pacific (Figure 1), contains clues to tectonic and paleooceanographic problems of much broader interest than might be expected from its relatively small size. The basin is defined on two sides by aseismic ridges; contains the Galapagos Rift Zone and Coiba Fracture Zone which form part of the boundary between the Nazca and Cocos lithospheric plates; underlies a region of high gradients in biologic productivity which reflect complex patterns of surface water circulation; and occupies a position adjacent to the Central American seaway which linked the Pacific and Atlantic Oceans prior to the late Miocene.

Van Andel et al. (1971) have suggested, on the basis of diverse geophysical data, that the basin formed by the north-south separation of the Cocos and Carnegie Ridges which once made up an ancestral Carnegie Ridge. The origin of the ancestral ridge is unclear, although a number of workers (Morgan, 1971; Holden and Dietz, 1972) have suggested that such features consist of a pile of volcanic rock formed as a lithospheric plate drifts over a magma source ("hot spot") deep in the mantle. In this hypothesis, the Galapagos Islands mark the present position of the "hot spot." One of the prime objectives of the three Leg 16 sites
(DSDP 155, 157, and 158) in the Panama Basin was to test the tectonic theories by determining the age and nature of volcanic basement and by relating changes in the nature of sediments deposited at the three sites to relative and absolute plate movements.

In addition, DSDP 157 and 158 were planned to evaluate changes in oceanic circulation and productivity during the late Cenozoic. DSDP 157, in particular, lies on the northern edge of the Peru Current where it swings west from South America to join the equatorial current system. Thus, this site is well placed to detect past changes in the position and intensity of the Peru Current due to the climatic deterioration and changes in atmospheric circulation of the late Tertiary and Pleistocene. The micropaleontologic studies reported in this volume provide a first look at biologic consequences of these phenomena. A full evaluation awaits more detailed paleoecologic work.

In the following discussion, data from DSDP 84 (Figure 1), drilled on Leg 9 (Hays et al., 1972), have been used to supplement the Leg 16 results.

\section{GEOLOGIC SETTING}

Figure 2 shows the principal tectonic elements of the Panama Basin in relation to the DSDP sites. DSDP 84 is in the basin proper close to the Coiba Fracture Zone (the 


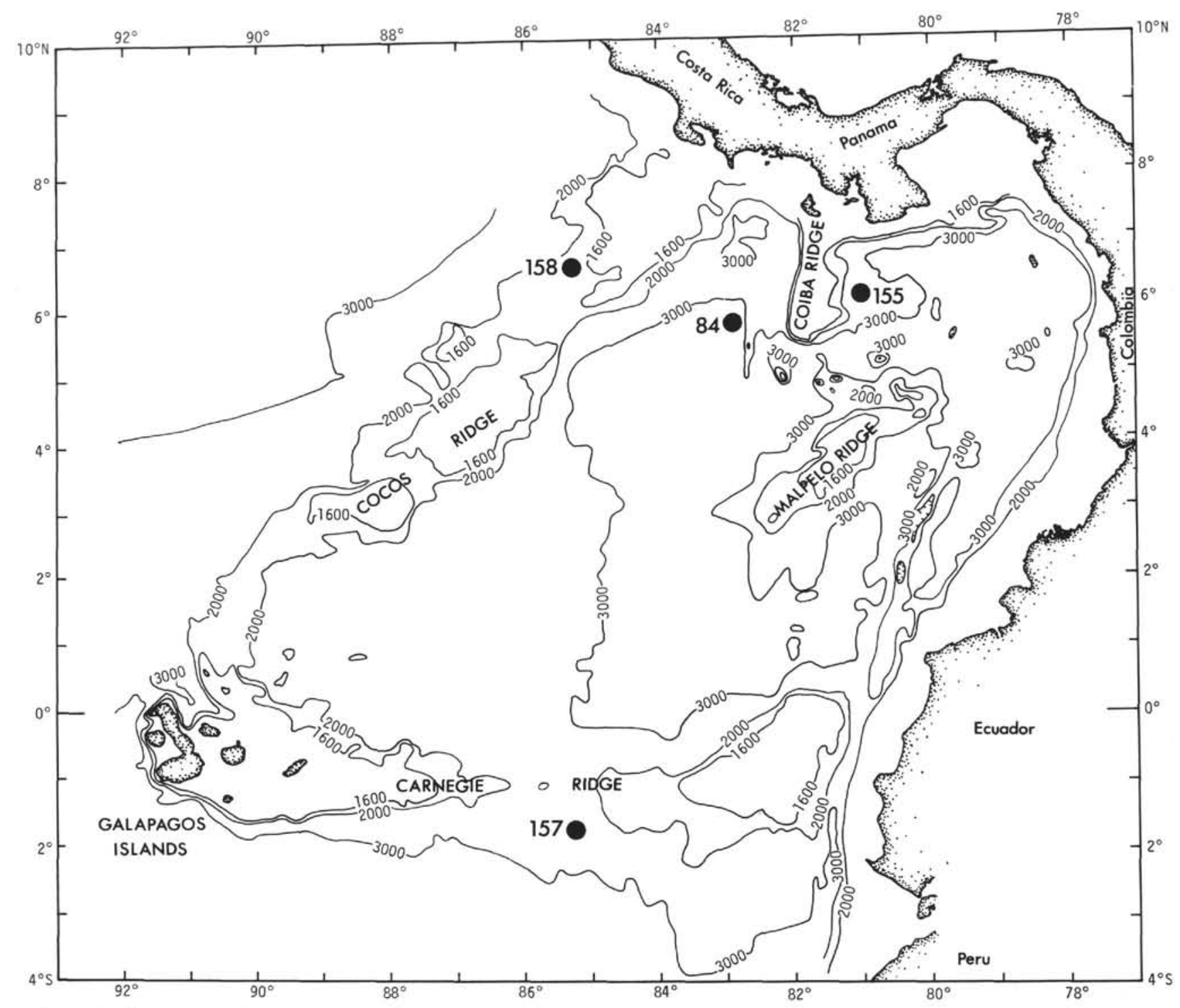

Figure 1. Location of DSDP sites in the Panama Basin relative to bathymetry (simplified from van Andel et al., 1971) and to major topographic features.

transform fault forming the eastern boundary of the Cocos plate). In contrast, the three Leg 16 sites lie on topographic highs, well above the 3000-meter average depth of the basin. These locations were chosen because they have the thickest sections of pelagic and hemipelagic sediments in the area and because all the tectonic interpretations in circulation prior to Leg 16 suggest that the ridges are older than the depressed areas.

All three major ridges (Coiba, Cocos, and Carnegie) are in isostatic equilibrium, that is, they are not dynamically elevated features. They are bounded by normal faults (Figure 3) which are separated by essentially horizontal terraces. Along the south side of the Carnegie Ridge, where the faulted terrain has been studied in greatest detail, the terraces are up to $100 \mathrm{~km}$ long and $20 \mathrm{~km}$ wide. The uniform depths along the terraces suggest that the ridges formed by stepwise faulting of a flat or gently domed surface, rather than by volcanic outpourings.
The sedimentary cover on the ridges is irregular. The thickest sections are found in graben-like depressions (DSDP 158, Chapter 5, this volume) or on flank terraces (DSDP 157, Chapter 4, this volume). Three to five hundred meters of sediment are commonly observed over smooth acoustic basement in such areas. Sediments on exposed structural blocks are commonly eroded. In extreme cases, such as the central crest of the Carnegie Ridge, virtually no sediment remains above acoustic basement (Figure 4). On the flanks of the ridges, channeling is more common. On the south side of the Carnegie Ridge, the channels have cut through to acoustic basement (Figure 5). Some of the eroded material appears to have been trapped on flank terraces (Figure 5), but most has been carried to the floor of the basin or to the abyssal sea floor outside.

The smooth acoustic basement with its cover of stratified sediment is interrupted by numerous small volcanic pinnacles which are usually more or less circular in plan and 


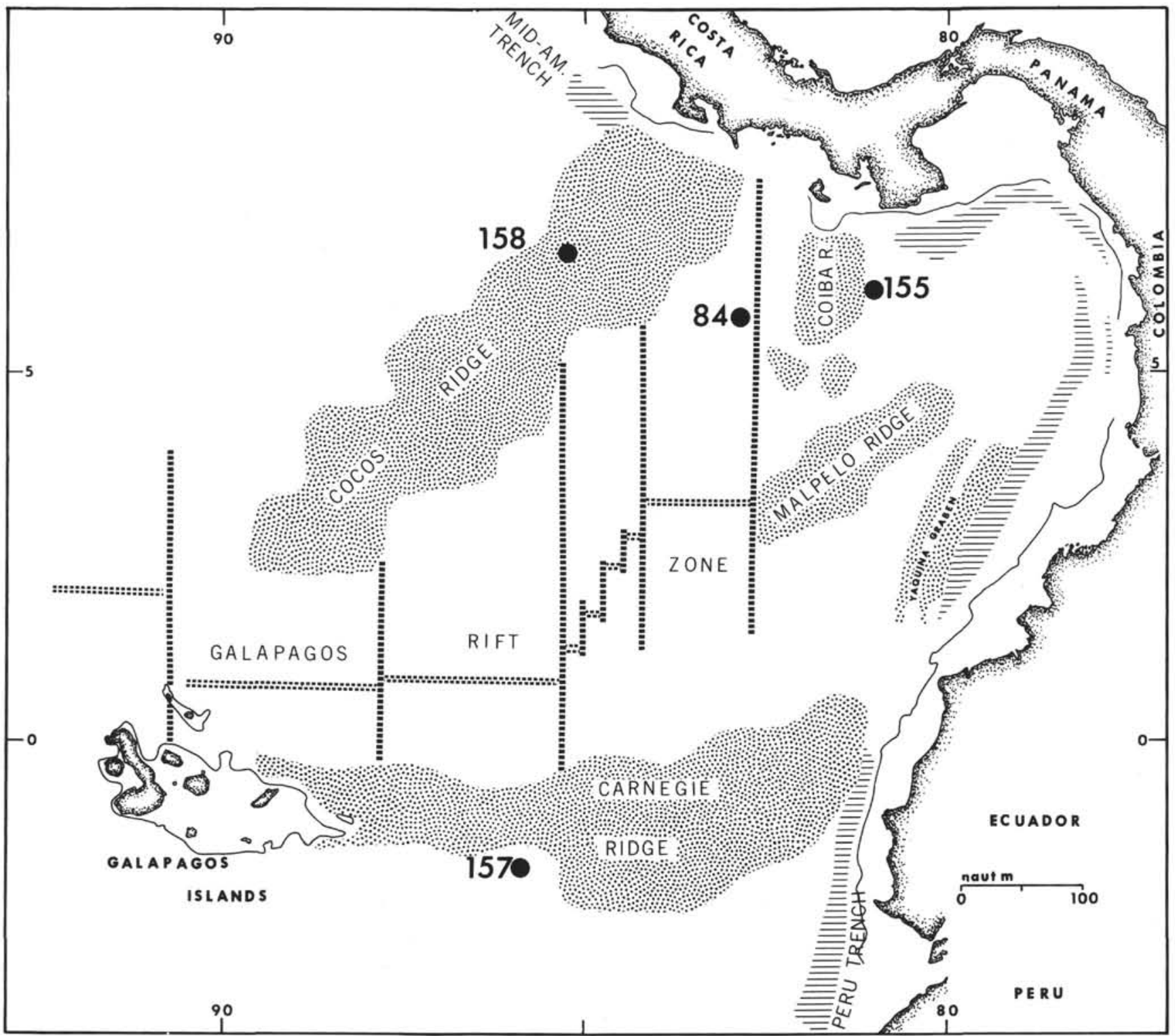

Figure 2. Major tectonic features of the Panama Basin. Single dashed lines, fracture zones; double dashed lines, spreading centers; stippled areas, topographic highs; cross hatched areas, trenches or marginal depressions. After van Andel et al. (1971).

one to several hundred meters high. Volcanic features, which produce very strong reverberation in $12 \mathrm{kH}$ acoustic records, are easily distinguished from peaks produced by erosion of the sedimentary pile, even in older echo sounder records.

The distribution of acoustically defined sedimentary units in the Panama Basin is shown in Figure 6 (after van Andel et al., 1971). Drilling at DSDP 157 and 158 has established that the smooth acoustic basement is chert which, as at DSDP 157, masks much of the sedimentary section. The inability of reflection profiler systems to "see" through the chert horizon is, perhaps, the main handicap in applying the Leg 16 drilling results to the tectonic history of the Panama Basin. We cannot be sure that DSDP 157 and 158 sampled the most complete sections in their areas, and we have no clue as to the relation of the basalt basement recovered to the origin of the ridges. Lest this sound too discouraging, we should emphasize that these problems apply to much of the Pacific Basin (as indicated by drilling results of Legs $5-9$ and $16-17$ ) and that the data from the DSDP cores do place severe constraints on past tectonism, albeit not as severe as we might wish.

The tectonic model developed by van Andel et al.(1971) is summarized in Figure 7 (after Malfait and Dinkelman, 1972). Basically, the model assumes a pre-existing Carnegie Ridge which drifted towards South America and collided with it about 25 million years ago. Presumably as a result of the collision, the ancestral Carnegie Ridge began to split from east to west, and the fragments split off drifted north to form the Cocos and more easterly ridges of the northern 


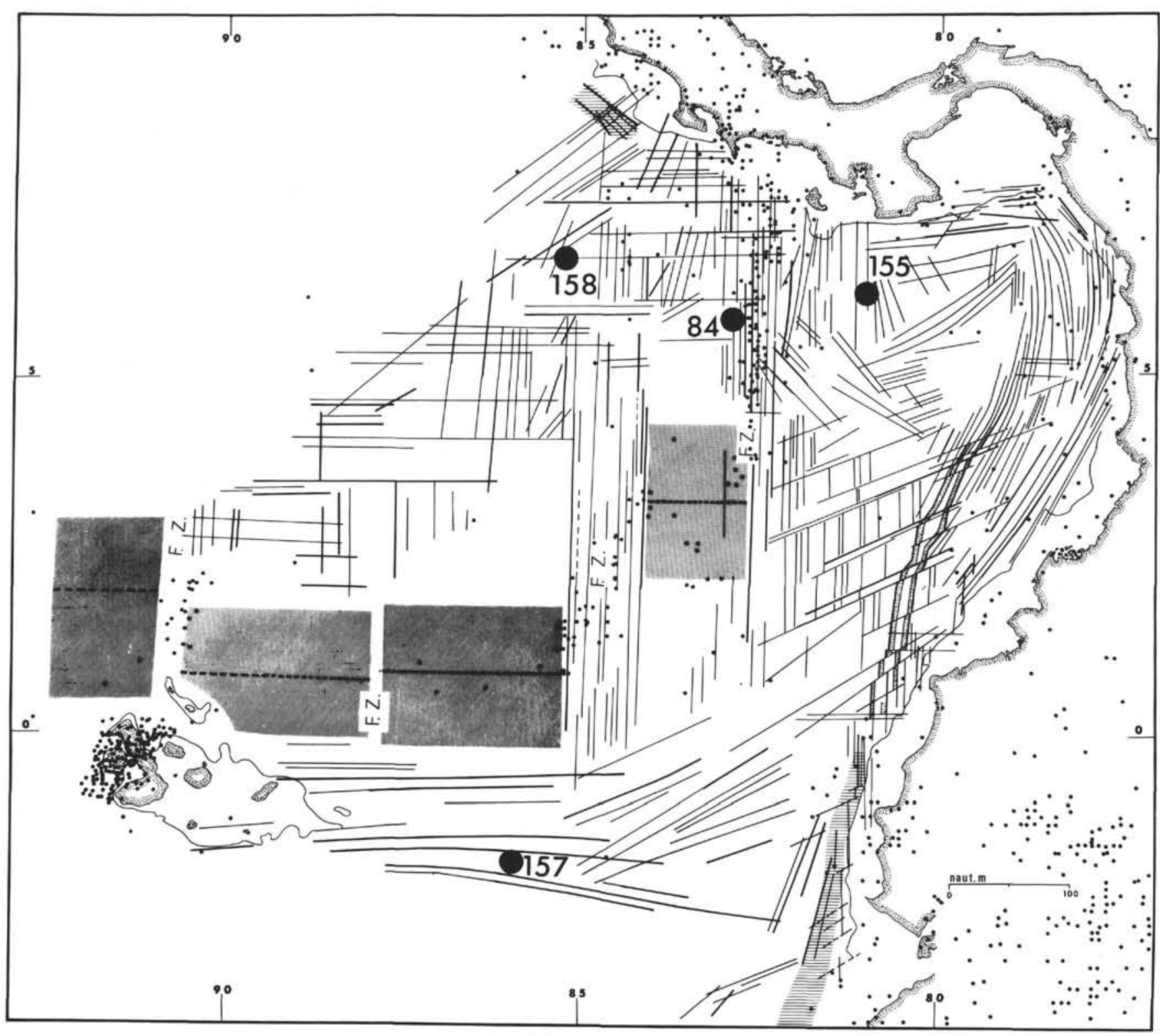

Figure 3. Distribution of earthquake epicenters (data provided by National Oceanographic and Atmospheric Administration) and fault traces in the Panama Basin. Trenches horizontally hatched; inner scarps of Yaquina graben stippled, Galapagos Rift Zone shaded. See van Andel et al. (1971) for control.

Panama Basin. As the fragments reached the Middle America Trench, they plugged and deactivated the subduction zone, forcing the eastern transform fault boundary of the Cocos Plate to jump progressively westward. Rapid uplift of Central America from oceanic depths (continuing today) is attributed to isostatic rebound of the plugged subduction zone. Subsequent to the Leg 16 drilling, Holden and Dietz (1972) proposed an alternative hypothesis which differs somewhat from the earlier model in assuming complete separation of the Cocos and Nazca plates since at least the mid-Oligocene. The Holden-Dietz model suggests that the Cocos and Carnegie Ridges consist of volcanic debris extruded on to lithospheric plates drifting across a mantle "hot spot" (Figure 8). Holden and Dietz (1972) also suggest that the Carnegie and Cocos Ridges have been separate features throughout their histories (a binematath system using Carey's nomenclature), whereas van Andel et al. (1971) derive the Cocos and Coiba Ridges from an ancestral Carnegie Ridge (Figure 7), implying east to westward development of the Cocos Plate at the expense of a former Nazca (or east Pacific) Plate.

DSDP 155,157 , and 158 were, in part, designed to test the van Andel et al. (1971) model. Although not optimally located for the purpose, they can also test some aspects of the Holden-Dietz hypothesis.

The Leg 16 Panama Basin sites were also designed to study the paleo-oceanographic history of the easternmost equatorial Pacific. This area includes the highly productive Gulf of Panama area, as well as biologically rich zones along the northern margin of the Peru current system (above the 


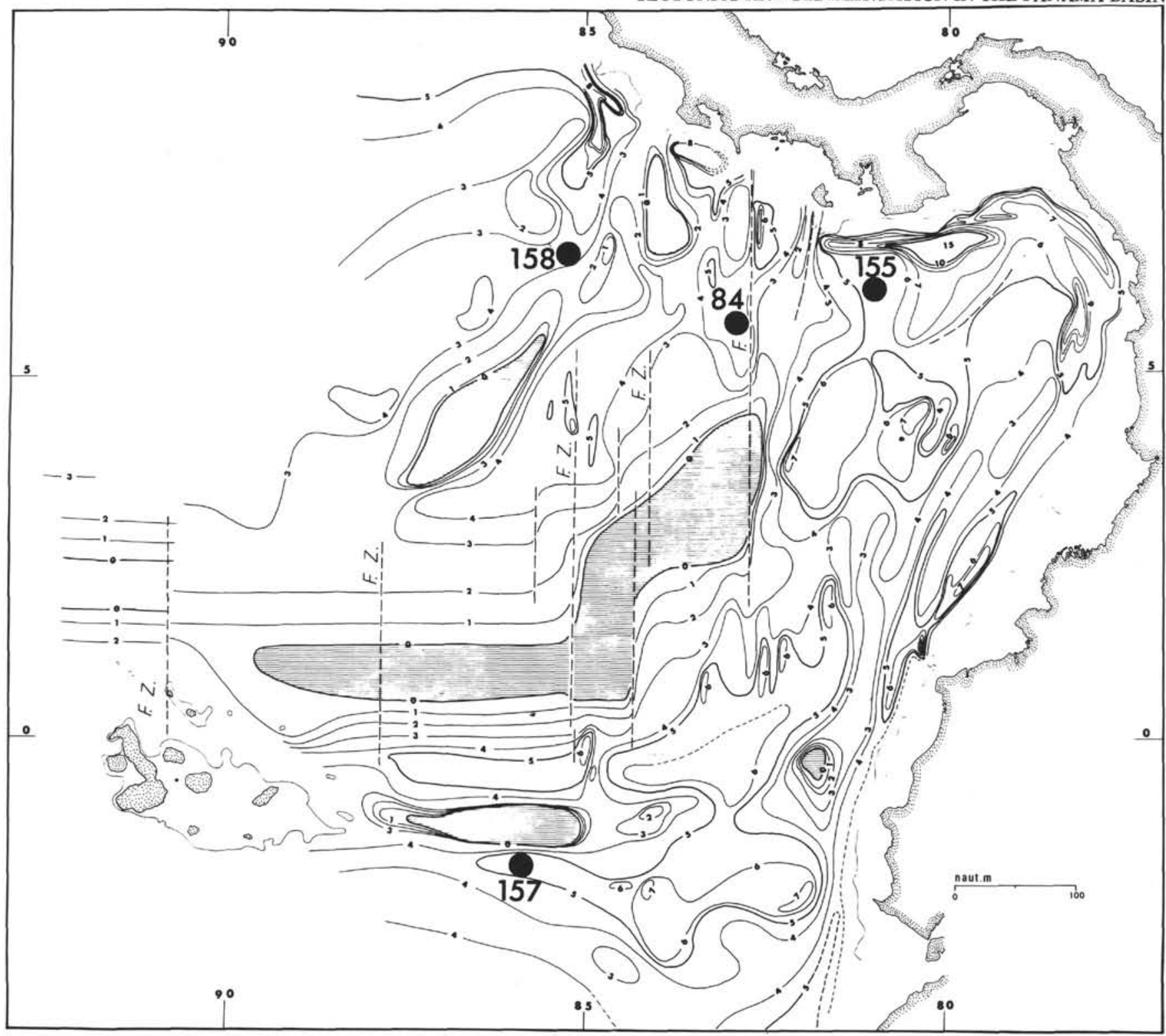

Figure 4. Thickness of sediment above acoustic basement in tenths of seconds two-way travel time. Multiplying these figures by 80 yields approximate sediment thicknesses in meters. Horizontally hatched areas are young crust along the Galapagos Rift Zone or eroded crests of the Cocos and Carnegie Ridges. After van Andel et al. (1971).

Carnegie Ridge) and the southern margin of the Costa Rica dome (just north of the basin). Current theories on the effects of climatic change on ocean currents suggest an equatorward compression and intensification of the major circulation pattern during glacial periods. If so, the eastern Leg 16 sites, and DSDP 157 in particular, should record the effects of accompanying productivity changes and temporal variations in water temperature. DSDP 157,84 , and 158 were all cored continuously to basement in order to recover as much as possible of the sedimentary and paleooceanographic history of the region.

Figures 9 and 10 show, respectively, the present distribution of total sediment less than $2 \mu$ in diameter and of calcium carbonate (tests of foraminifers and coccoliths) at the sea floor (after Moore et al., in press). Both parameters are correlated with bottom topography; fine sediments are usually found in depressions and carbonate-rich deposits on ridges. The carbonate distribution reflects, in part, the effect of solution - the compensation depth in the area is about 3500 meters. In addition, it reflects redistribution by bottom currents (Moore et al., in press). The most carbonate-rich deposits are relict foraminiferal sands left after the finer opaline and terrigenous phases have been winnowed away. The lens of fine sediment immediately north of the eroded crest of the Carnegie Ridge (Figure 9) suggests that most of the winnowed material is deposited close to its source.

Even from this cursory review, it is clear that the sediments of the Panama Basin area record dynamic processes near the sea floor. The cores from the DSDP holes provide a window into the past history of such conditions in the basin. 


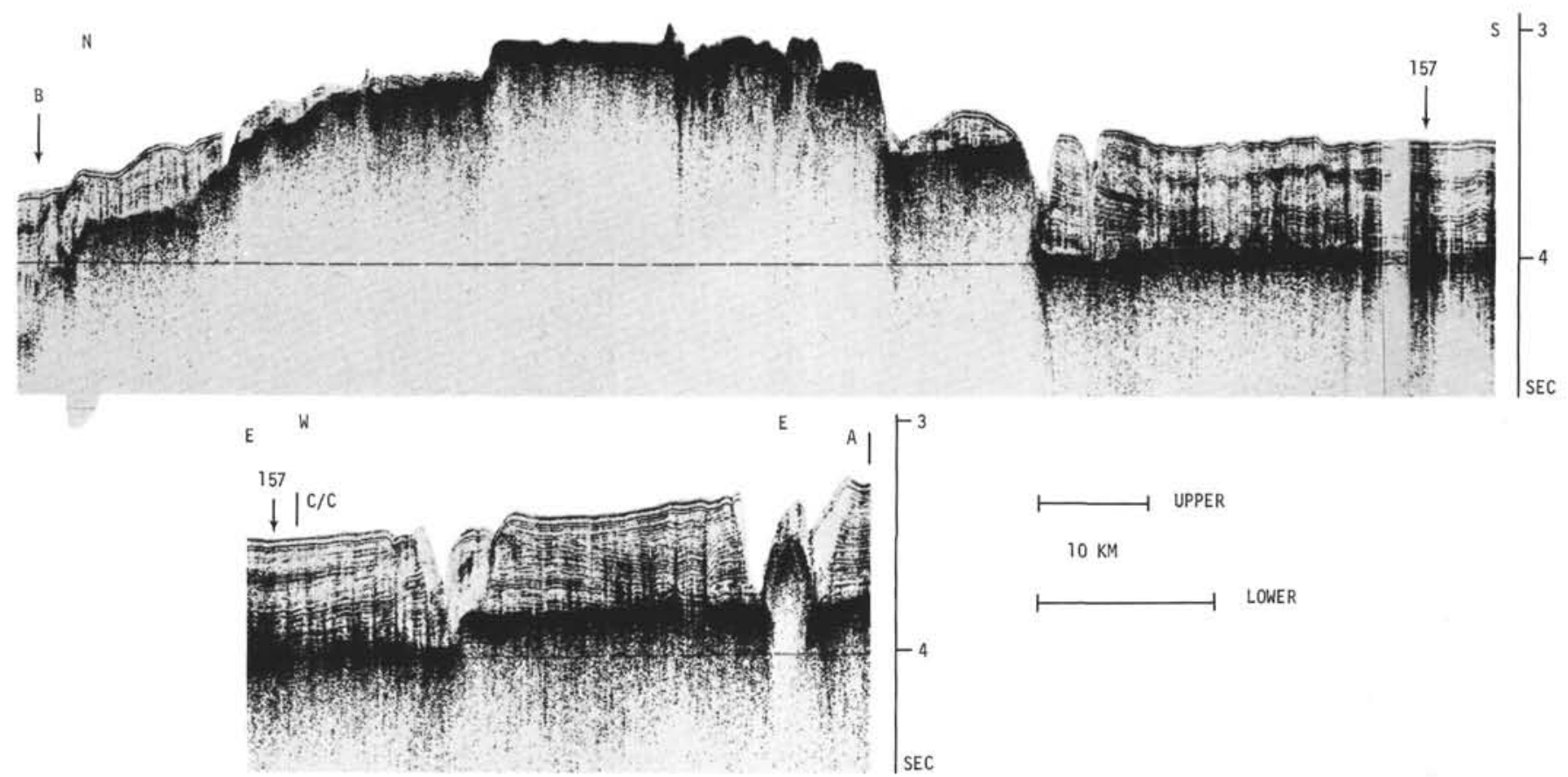

Figure 5. Reflection profiler records running east and north from DSDP 157, showing deeply dissected flank sediments of the Carnegie Ridge and evidence of lateral reworking within the sediment column. Vertical scale in seconds 2-way travel time; horizontal scale approximate. See Chapter 4, this volume, for profile locations.

\section{DRILLING RESULTS}

\section{Sediments}

The detailed descriptions of sediments from DSDP 155 through 158 can be found in Chapters 2 through 5 of this volume. The gross lithology and stratigraphy of these sites and of DSDP 84 are summarized in Figure 11. All sections are calcareous throughout, although not strikingly so for the equatorial Pacific. Opaline silica and fine inorganic detritus make up most of the remainder. Recognizable ash beds are largely restricted to the upper part of DSDP 158 and to DSDP 84. Montmorillonite and montmorillonitecristobalite-rich claystones from DSDP 155 may be altered volcanic debris ("bentonites"), but"the lack of identifiable shard pseudomorphs leaves the interpretation in some doubt.

The tectonic and paleo-oceanographic information preserved by the sediments is somewhat blurred in the deeper parts of the section by diagenesis. As already mentioned, the clay units of DSDP 155 have been sufficiently altered that their origin is now uncertain. In addition, the DSDP 155 sediments contain discordant bodies of carbonate, barite, and pyrite, all indicative of post-depositional redistribution of sedimentary components. For this reason, the DSDP 155 cores are less suitable for geochemical studies than those from the other Panama Basin sites. In DSDP 157 and 158 , silica mobilization is ubiquitous below the youngest chert horizon. Some recrystallization of calcite has occurred (Bukry, Chapter 26, this volume), but there is no evidence that this has been severe enough to markedly alter the carbonate profiles at the two sites.

Figure 12 provides an overview of the sediment budgets at the DSDP sites in the Panama Basin for the past 7 million years. The time units are Bukry's nannofossil zones (Chapter 26, this volume). Any errors in the age assignments of zone boundaries will be reflected in the estimated sedimentation rates, but all histograms will be affected in the same way. In this regard, the curves are more suitable for detailed comparison than are the integrated rate curves of the site chapters. The rates for the oldest zone at DSDP 84 and 155 are minimal because DSDP 84 reached basalt above the base of the zone, and the top of the zone was not cored at DSDP 155.

In general, the sedimentation rate throughout the area was remarkably uniform from about 5 to 7 m.y. ago, immediately after the formation of the crust at DSDP 84 . At this time, all four sites were within 3 degrees of latitude of one another (according to van Andel et al., 1971). The basal sediments are all carbonate-rich $\left(\sim 70-80 \% \mathrm{CaCO}_{3}\right)$ and, in this respect, resemble modern sediments at DSDP 157 much more than at the other sites. At present, such high carbonate values are largely restricted to areas west of about $87^{\circ} \mathrm{W}$ and shallower than about 2000 meters (Figure 9). It is reasonable to assume that as DSDP 84 was formed at the Galapagos Rift Zone, all four DSDP sites were far enough from Central America and shallow enough to lie in a comparable depositional regime. The deeper calcite compensation depth that apparently prevailed at the time (Heath, 1969; Chapter 37, this volume) would reinforce the location and depth effects.

From $5 \mathrm{~m} . \mathrm{y}$. ago to the present, the depositional regimes at DSDP 84,157 , and 158 diverge markedly. The sedimentation rate and carbonate content at DSDP 157 (Figures 12 and 13) show the least variability. Thus, the present topographic and oceanographic settings of this site have probably changed little during the past 5 million years. The 


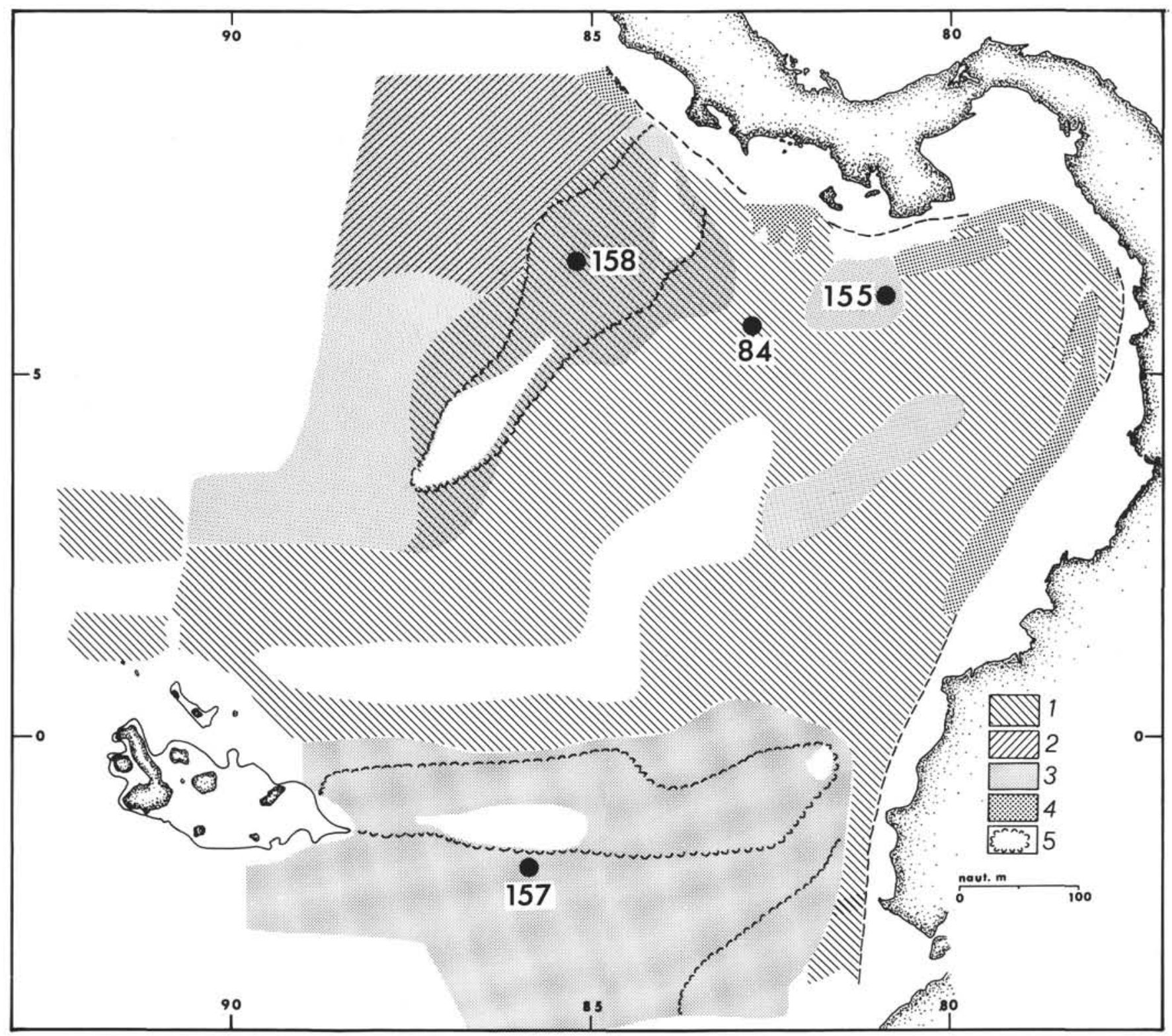

Figure 6. Distribution of acoustically defined sediment types in the Panama Basin area. See van Andel et al. (1971) for control. Legend: (1) semitransparent deposits; (2) thin transparent layer of the eastern Pacific basin; (3) stratified complex; (4) hemipelagic deposits; (5) limits of eroded portions of Cocos and Carnegie Ridges. Blank areas are free of sediment or contain only local patches.

peak in sedimentation rate about 2 to 3 m.y. ago corresponds to an irregular carbonate minimum (Figure $13)$, to an interval of etched nannofossils (Bukry, Chapter 26 , this volume), and to an interval of reworked radiolarians. This evidence, together with the complex patterns of erosion and deposition evident in reflection profiler records (Figure 5) suggest that from 3 to 2 m.y. ago, DSDP 157 received an important contribution of laterally reworked sediment.

From about 5 to 4 million years ago, the deposition rates at both DSDP 84 and 158 dropped to about 20 $\mathrm{m} / \mathrm{m} . \mathrm{y}$. (Figure 12), but carbonate deposition continued at about the same levels. Such a pattern suggests that the intensity of sedimentation changed, but its character did not. Northward drift of DSDP 84 and 158 out of the productive zone at the northern edge of the Peru Current system might produce such a change, although the present day relation between surface biologic productivity and sediments in the area is largely masked by secondary reworking of the biogenic particles at the sea floor. Careful examination of reflection profiler records (like Figure 5) suggests that erosion and redeposition of sediments has been important throughout the history of the Panama Basin. Presumably, the preservation or destruction of primary depositional patterns depends largely on the scale of the reworking processes. Three drill sites are too few to estimate this scale with much confidence, but it does appear that primary early Pliocene depositional characteristics are better preserved than modern ones.

From 4 to about 1 million years ago, the depositional histories of DSDP 84 and 158 diverge strongly (Figure 12). Since the relative positions of the sites did not change 


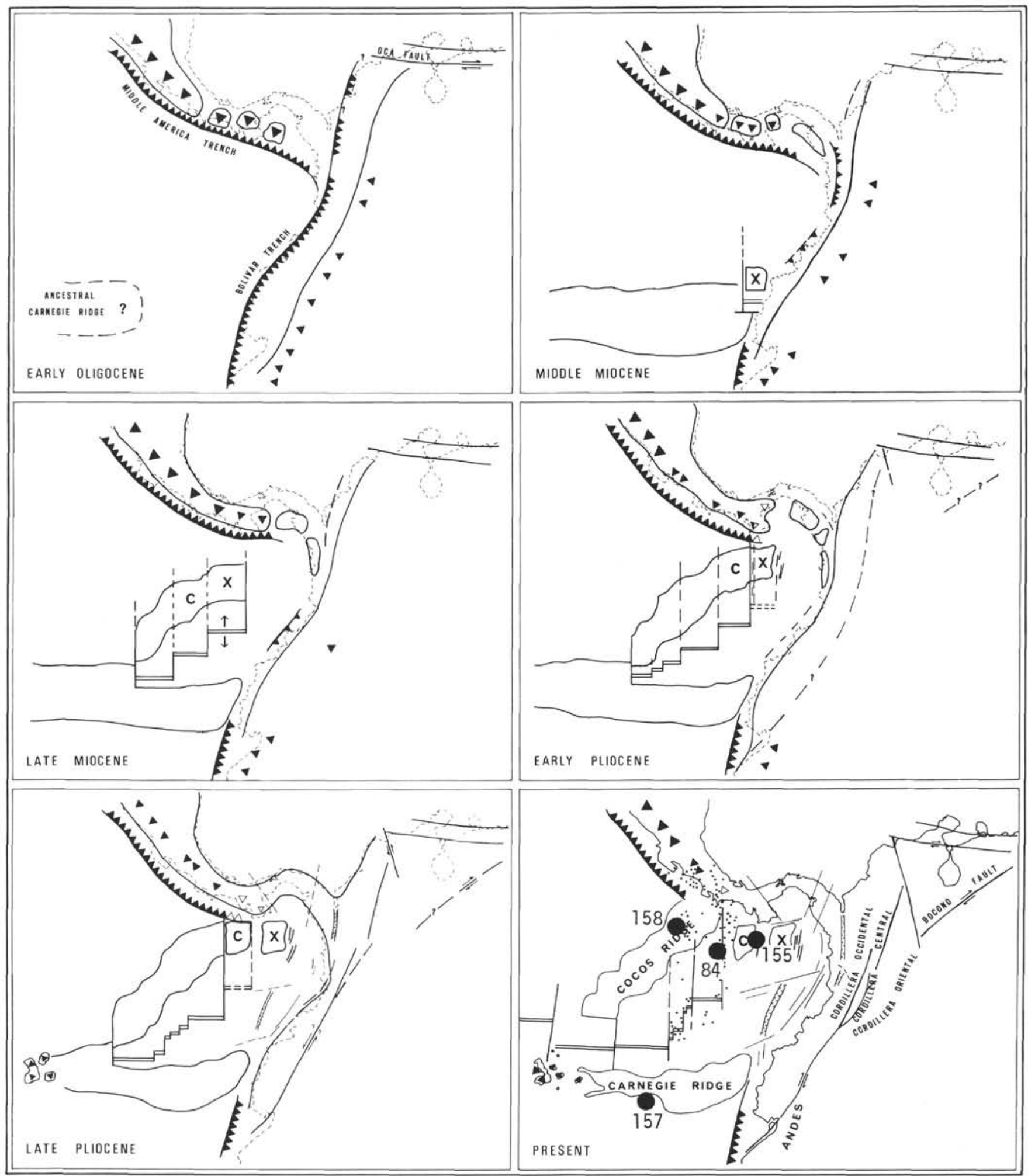

Figure 7. Structural development of the Panama Basin as visualized by van Andel et al. (1971) and embellished by Malfait and Dinkelman (1972). Sawtooth lines, subduction zones; triangles, volcanoes (solid-active, open-extinct); single lines, faults or fracture zones; double lines, spreading centers; dots (PRESENT only), earthquake epicenters. $C$ and $X$ are fragments broken from the end of the Cocos Ridge after they plugged and deactivated the subduction zone of the eastern Middle America Trench. 


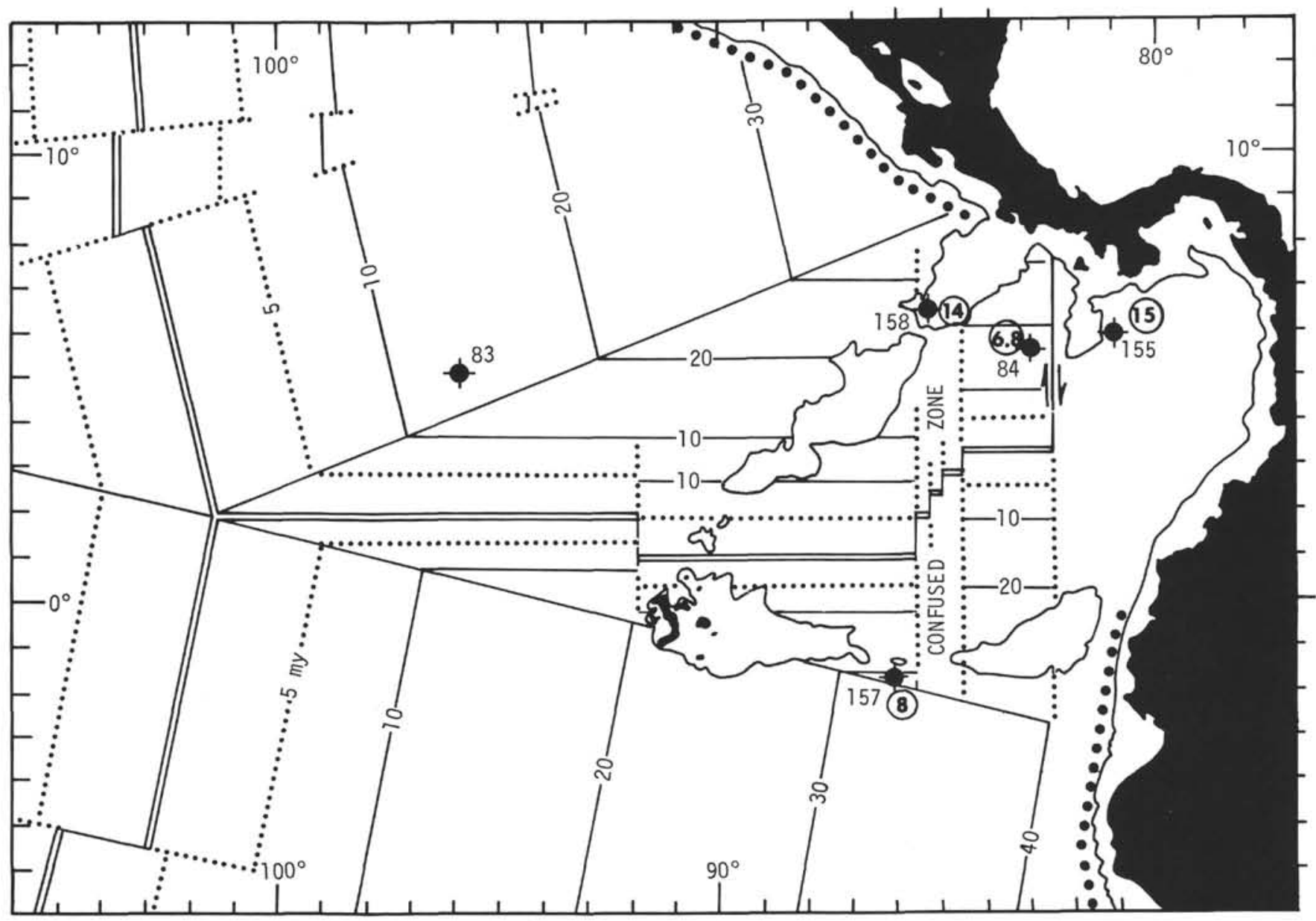

Figure 8. Seafloor isochrons for the eastern equatorial Pacific as visualized by Holden and Dietz (1972). Circled numbers beside DSDP sites are paleontologically estimated basement ages. Much of the discrepancy can be overcome by assuming spreading rates of 1.5 to 2 times those of Holden and Dietz. The locations of boundaries between crust generated at the East Pacific Rise and at the Galapagos Rift Zone are poorly known.

during that interval (they are both on the north flank of the Galapagos rift and have been drifting north relative to DSDP 157 at $5-6 \mathrm{~cm} / \mathrm{yr}$ ), the change in depositional regimes must reflect divergent tectonic, oceanographic, and sedimentological influences. At DSDP 84, the sedimentation rate increases slightly from 4 to $1 \mathrm{~m} . y$. ago (Figure 12), whereas the carbonate content of the sediment decreases by a factor of four (Figure 13). Clearly, the deposition rate of calcite has decreased while the nonbiogenic input (both volcanic and terrigenous, judging by the X-ray results of Cook and Zemmels, 1972) has increased. This pattern is probably due to a combination of at least four factors: (a) reduced carbonate productivity over the site; (b) increased dissolution of calcite as the site moved into deeper water, as the compensation depth rose during the late Cenozoic, and as the nearshore shoaling of lysocline and compensation depth began to become apparent; (c) increased input of volcanic debris as the site moved northward at 50 to $60 \mathrm{~km} / \mathrm{m}$.y. into the "shadow" of the Coiba Ridge; and (d) increased influx of terrigenous debris as the site moved towards Central America.

The picture at DSDP 158 is similar in that the carbonate content of the sediment decreased during the late Pliocene and early Pleistocene (Figure 13), but differs markedly in that the deposition rate dropped steadily from 4 to $1 \mathrm{~m} . \mathrm{y}$. ago. Clearly, the reduced carbonate content of these sediments cannot result from dilution by other sediment. Rather, there must have been a marked reduction in the rate of supply of calcite to the sea floor or an increase in the aggressive character of the bottom waters leading to accelerated dissolution, or both. The latter option is consistent with the observation that the lysocline (as well as the calcite compensation depth) rises at the margins of ocean basins. Modern deposits from the vicinity of DSDP 158 contain strongly dissolved calcitic tests (Kowsmann, 1973). Together with Bukry's (Chapter 26, this volume) report of etched nannofossils in the Plio-Pleistocene section at the site, this confirms the influence of calcite dissolution on deposition in the area. Although much of the reduced sedimentation rate can be attributed to a lower rate of carbonate accumulation, the hiatus near the PlioPleistocene boundary points to the influence of bottom transport and erosion (Chapter 11, this volume). The increased intensity of these processes may have resulted from the development of the topographic Panama Basin, from the influence of contour currents along the ever closer 


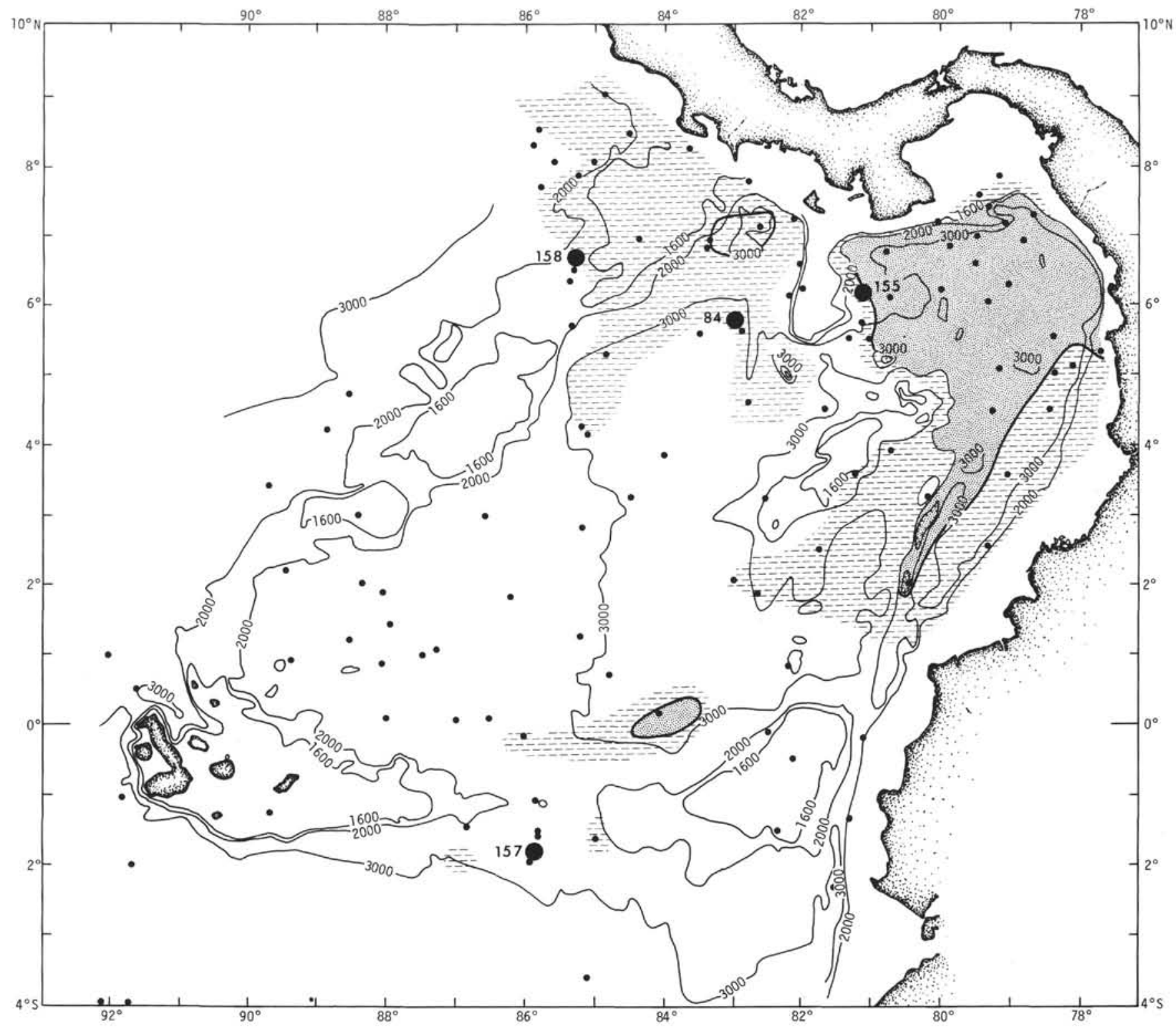

Figure 9. Less-than-2-micron fraction as a percentage of surface sediments of the Panama Basin. Dots are locations of cores analyzed. Heavy shading, more than 60 percent; light shading, 40-60 percent; unshaded less than 40 percent. After Moore et al (in press).

landmass of Central America, or merely from local phenomena at DSDP 158. One drill hole cannot resolve the problem.

All three continuously cored Panama Basin sites record increased sedimentation rates during the second half of the Pleistocene (Figure 12). This increase is not accompanied by a change in the carbonate content of the deposits (Figure 13), suggesting an intensification of both biogenous and nonbiogenous sedimentation rather than any fundamental change in the overall regime. Similar changes are common in the Pacific and probably result from intensified oceanic circulation (with its associated productivity increase) and increased continental erosion resulting from Pleistocene climatic changes. The spacing of samples and the disturbed character of the DSDP cores does not allow us to resolve the detailed carbonate stratigraphy previously recognized in the eastern equatorial Pacific (Arrhenius,
1952; Hays et al., 1969). All three continuously cored sites have a carbonate maximum at about $1.1 \mathrm{~m} . \mathrm{y}$. ago. This does not correlate well with the carbonate curves mentioned previously, but its significance is uncertain because of the imprecise dating of the DSDP material in this interval and because of the sampling problems associated with the Glomar Challenger cores (Moore, 1972).

Preliminary micropaleontologic data suggest that the DSDP cores record a complex paleo-oceanographic history in the Panama Basin area. Temperatures at DSDP 157, based on silicoflagellate abundances (Bukry and Foster, Chapter 29, this volume), increased from about $25.5^{\circ}$ to $28^{\circ} \mathrm{C}$ during the past 5 million years - a trend clearly at variance with generally accepted estimates of global temperatures during this period. Similarly, variations in the character and abundance of diatom floras (Dinkelman, Chapter 28, this volume; Bukry and Foster, Chapter 25, 


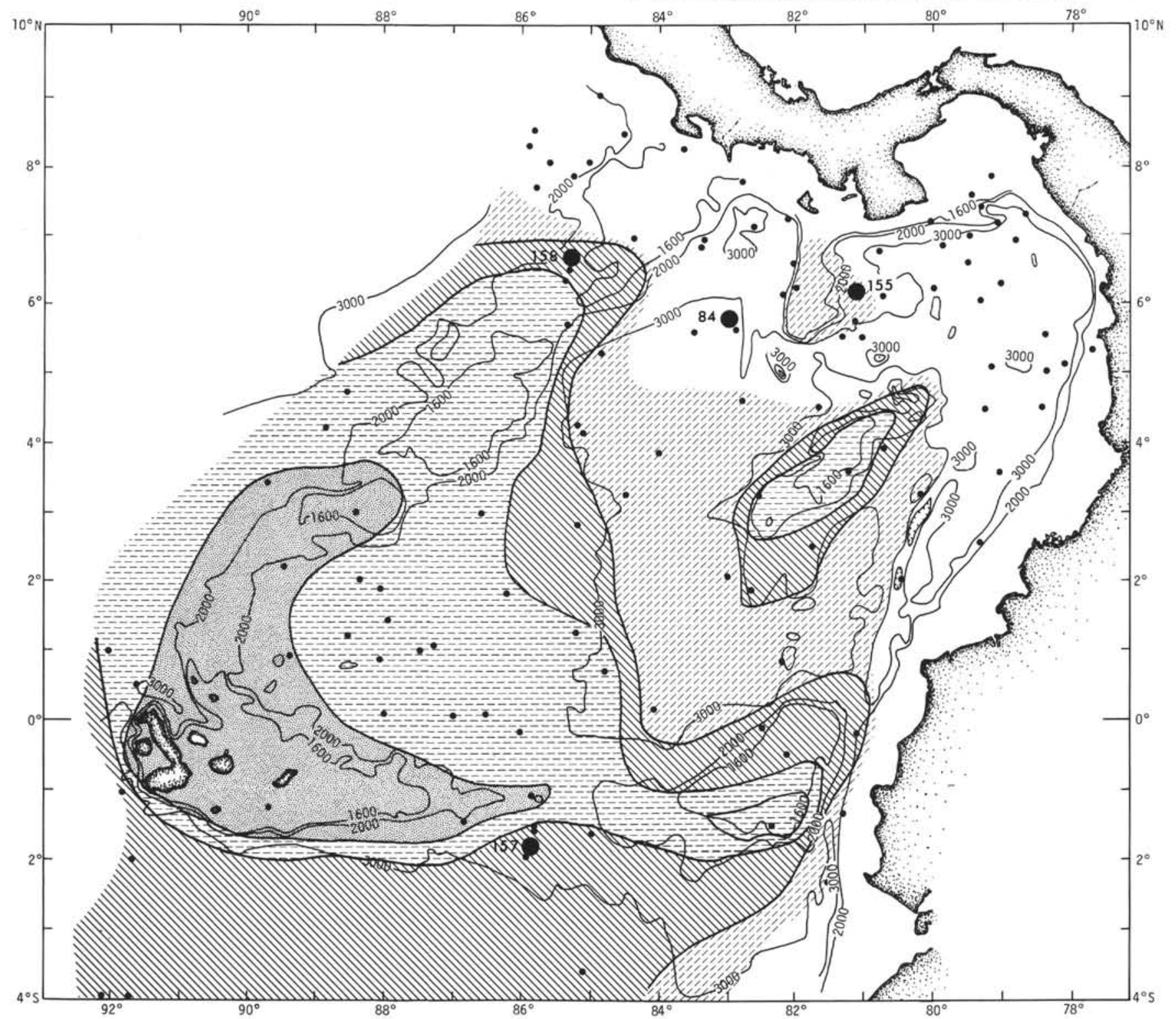

Figure 10. Abundance of calcium carbonate in surface sediments of the Panama Basin. Dots are locations of cores analyzed. Contour interval 20 percent (heaviest shading, more than 80 percent; unshaded less than 20 percent). After Moore et al (in press).

this volume) and nannofossils (Bukry, Chapter 26, this volume) reflect past movements of current boundaries and intrusion of "foreign" water masses carrying their characteristic planktonic assemblages. The nature of the changes is discussed in the various micropaleontologic chapters of this volume. A full synthesis must await more detailed studies, preferably biased towards paleo-ecology rather than biostratigraphy.

\section{Tectonics}

Prior to the Deep Sea Drilling Project, tectonic interpretations of the Panama Basin were based entirely on geophysical data, particularly locations of earthquake epicenters, magnetic anomaly patterns, and structure visible in reflection seismic profiles. Epicenter data are of little value in determining the tectonic evolution of an area, and, in an area as topographically complex and as close to the magnetic equator as the Panama Basin, magnetic anomalies are difficult to interpret in terms of the standard reversal sequence. It is therefore not surprising that many aspects of the evolution of the area are still unclear.

As a result of the DSDP Legs 9 and 16 drilling, we have additional data on the age and nature of volcanic basement and on the depositional history of the area as recorded in the cored sediments. These data can be used to evaluate the earlier, geophysically based tectonic theories.

The ages of basement at the four drill sites (DSDP 84, 6.8 m.y.; DSDP 155, 15 m.y.; DSDP 157, 8 m.y.; DSDP $158,13.9$ m.y.) are difficult to reconcile with either the van Andel et al. (1971) or Dietz and Holden (1972) models, although the large possible errors in these ages $( \pm 2-3$ million years) must be kept in mind (van Andel, 1972). In the former case, the young age at DSDP 157 and the disagreement between the DSDP 157 and 158 ages do not 


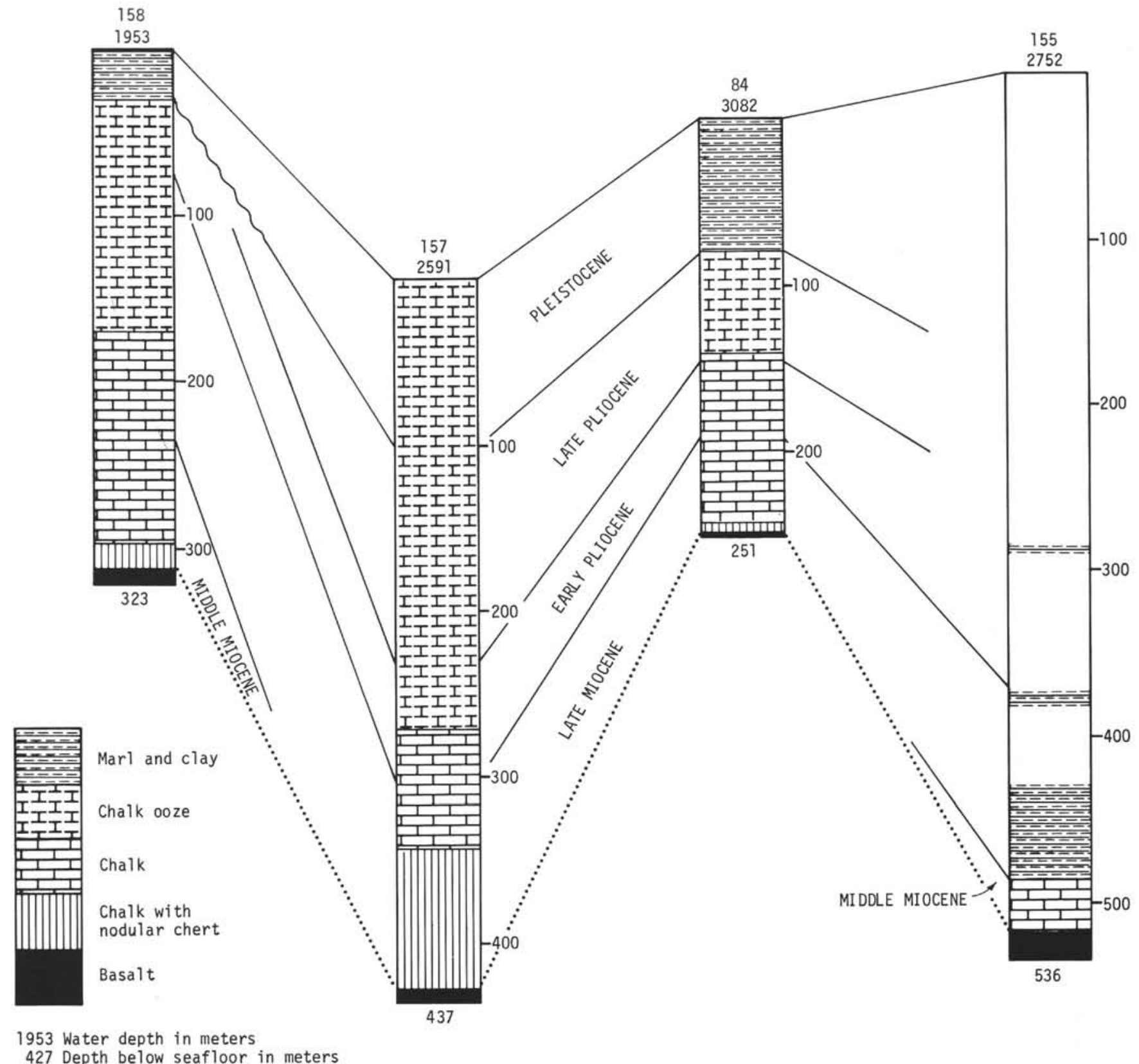

Figure 11. Generalized lithology and stratigraphy of the DSDP sites drilled in the Panama Basin. See individual site chapters for detailed descriptions.

fit the model. In the latter case, the predicted model ages are about twice the observed values. The disagreement may result from several factors. The simplest, of course, is that both theories are wrong. Because of the mass of evidence cited in the two papers, such a conclusion seems a little extreme. An alternative possibility is that later volcanic events have concealed the original crust and portion of the sedimentary record. Thus, if the basalt cored at DSDP 157 conceals seven or eight million years of depositional record, the van Andel et al. (1971) model becomes much more plausible. Similarly, if the Holden and Dietz model is correct, more than half the sedimentary column at all four sites has been buried by Miocene volcanism. Such a possibility cannot be disproved except by deep drilling, which was not feasible at the Panama Basin sites, but seems unlikely in view of the lack of alteration of the sediments immediately above basalt at all sites. In addition, reflection profiler records at DSDP 84 and 155 show no evidence of flows within the sedimentary section. Unfortunately, the topography and sediment-basement relations at DSDP 157 and 158 are concealed from the seismic profiler by highly acoustically reflective cherty chalks. This suggests another possibility. The drill may have reached basement high on the flank of a concealed depression, filled with horizontally stratified sediments. In such a case, the basement age inferred from the overlying sediment would be too young by an unknown, but possibly significant amount (see Chapter 37, this volume for additional discussion). 

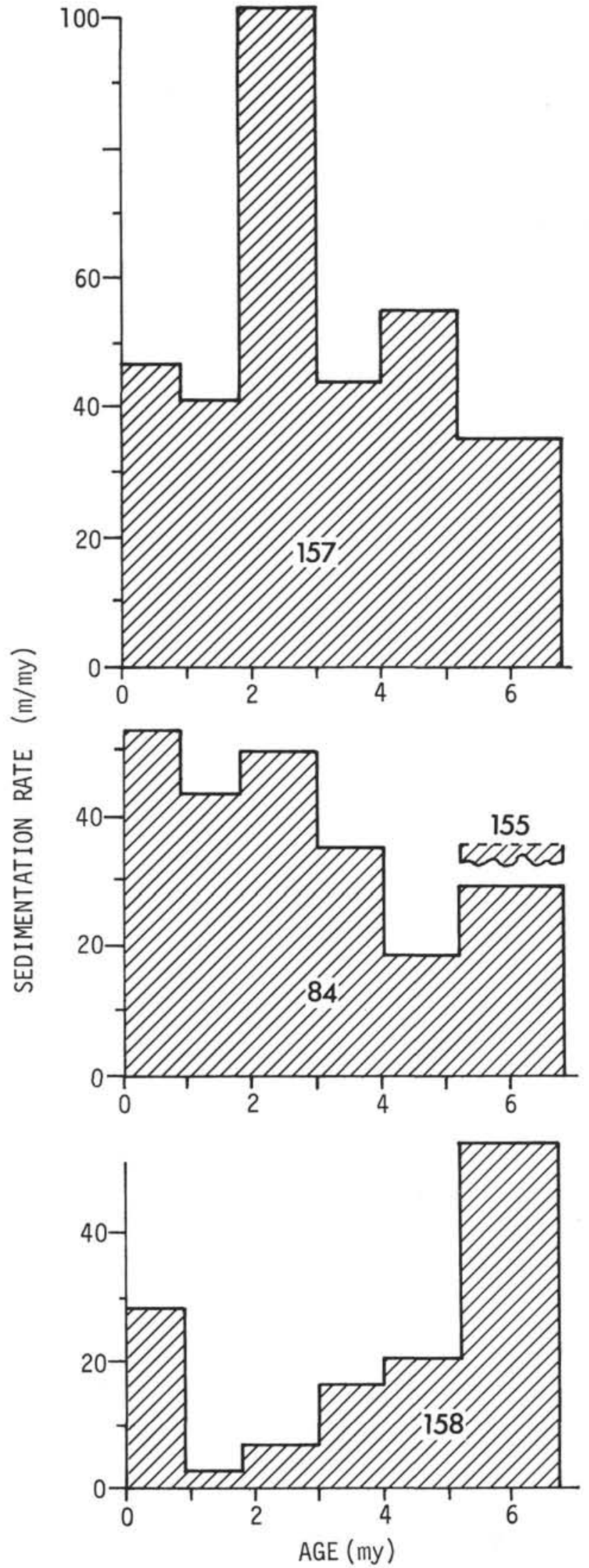

Figure 12. Late Miocene to recent sedimentation rates for continuously cored DSDP sites in the Panama Basin. Blocks in the histograpms are nannofossil zones from Bukry (Table 6, Chapter 26, this volume).
The basalts at DSDP 157 and 158 are tholeiites, whereas at DSDP 155 is an alkali basalt (Yeats et al., Chapter 22, this volume). Although the original chemistry of these rocks has been somewhat obscured by post-extrusional, low temperature alteration, it is clear from their rare-earth patterns (J. Corliss, pers. comm., 1972) that all three are more fractionated (i.e., alkaline) than the DSDP 159 through 163 basalts from the west flank of the East Pacific Rise. DSDP 155 was initially the most alkaline and has since taken up water and potassium from seawater.

Both the variability and fractionation evident in the analytical data are more consistent with derivation from a "hot spot" source than with formation at a normal spreading center. Thus, the illusion of upwarped and upfaulted deep-sea floor evident in north-south profiles across the Carnegie Ridge may be misleading and may result from down-to-the-basin faulting of the flanks of a volcanic pile as it cools away from its source region.

Unfortunately, the compositional data are of little value in determining whether the Leg 16 basalts are true basement rather than flows or sills concealing portion of the sediment column.

The third type of information provided by the drill holes, the depositional histories of the cored sections, has been discussed in the previous section. In general, all four sites appear similar until about $5 \mathrm{~m} . \mathrm{y}$. ago, then begin to diverge strikingly. This pattern is difficult to explain if Holden and Dietz's (1972) tectonic history is correct, as it suggests little change in the relative positions of the sites during this interval. In contrast, the van Andel et al. (1971) postulated breakup of the ancestral Carnegie Ridge is much more consistent with the depositional histories of the four sites.

Clearly, the drilling results of Leg 16 have not resolved the tectonic history of the Panama Basin. They do, however, provide some clues to the evolution of the area:

(1) The aseismic ridges are probably not simply uplifted oceanic seafloor. Rather, the step faults that form the sides of the ridges may result from thermal relaxation as the igneous mass of the ridges cool, or from deformation along the Galapagos Rift Zone (compare, van Andel and Heath, 1970).

(2) The ages of the oldest sediment at the four DSDP sites, if truly representative of basement ages, are not consistent with either the van Andel et al. (1971) or Holden and Dietz (1972) models. A much better fit can be obtained by combining aspects of the two models. Thus, if the ages of Holden and Dietz's isochrons (Figure 8) are roughly halved, and van Andel et al.'s picture of successive westward jumps of the east end of the Galapagos Rift as fragments of the Cocos Ridge plug and deactivate the Middle America Trench subduction zone is retained, a picture which is much more consistent with both geophysical and drill hole data emerges. D. Rea (personal communication, 1972) reports a spreading rate in excess of $8 \mathrm{~cm} / \mathrm{yr}$ at $6^{\circ} \mathrm{S}$ on the East Pacific Rise, lending support to the view that Holden and Dietz's model isochrons, which assumed a rate of $5.7 \mathrm{~cm} / \mathrm{yr}$, are much too old. However, the presence of acoustically opaque chert obscuring the true position of the drill sites with respect to basement precludes a final judgment. 


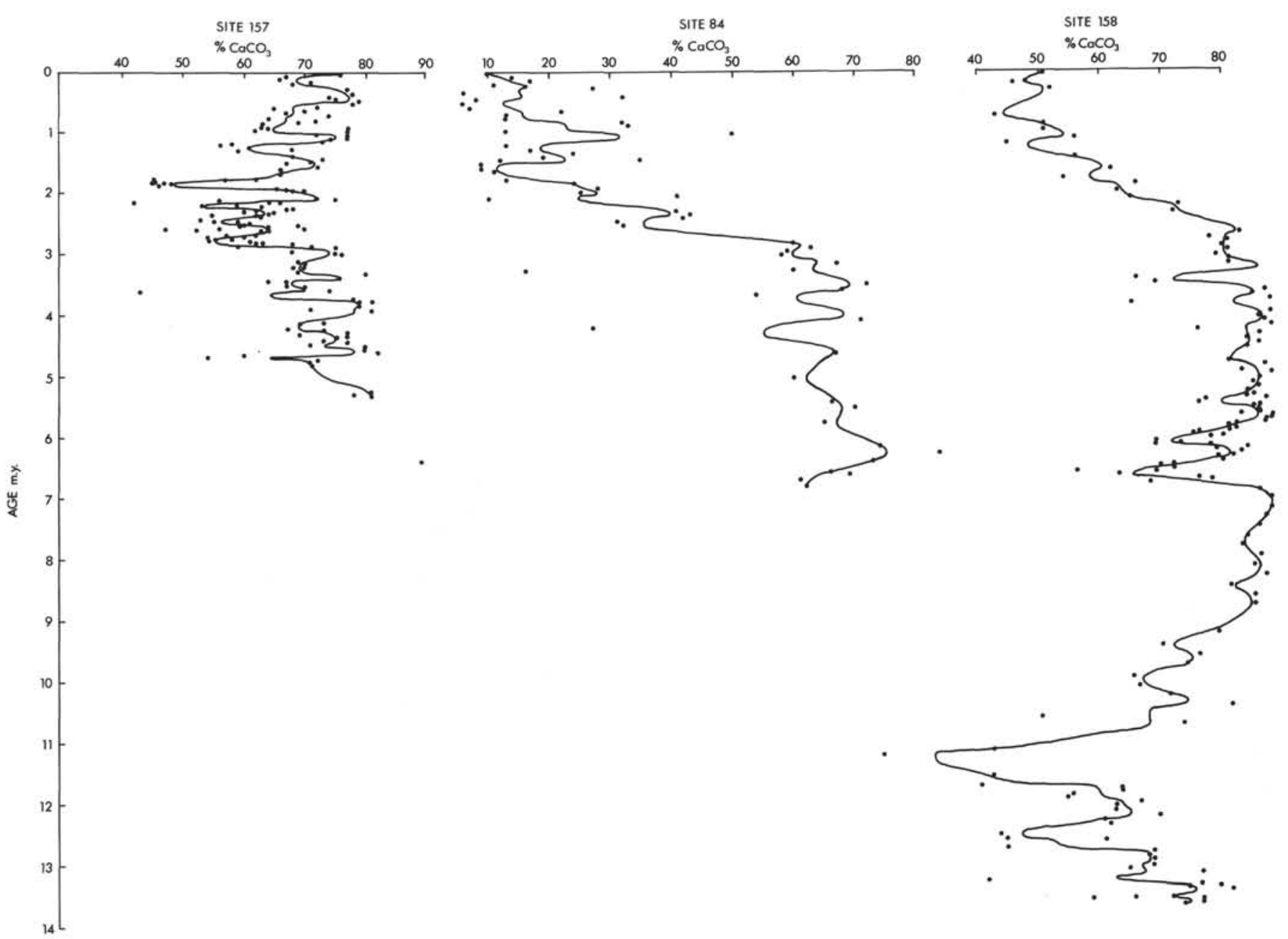

Figure 13. Carbonate contents of sediments at DSDP 157, 84, and 158 as a function of age. Lines are smoothed curves through the raw data from Chapter 14. Conversion of depths to ages based on Bukry (Chapter 26 this volume).

Although the presence of the chert layer will always make drilling results in the area difficult to interpret, it seems to us that additional sites along the Cocos and Carnegie Ridges, in combination with a detailed magnetic survey north of the Cocos Ridge and rift between the triple point and Galapagos Islands, are most likely to clarify the tectonic history of the easternmost equatorial Pacific, including the Panama Basin.

\section{ACKNOWLEDGMENTS}

We are grateful for suggestions and critical discussions with our scientific colleagues, aboard Glomar Challenger and at Oregon State. Comments by T. C. Moore, Jr. and J. B. Corliss have been particularly helpful.

\section{REFERENCES}

Arrhenius, G. O. S., 1952. Sediment cores from the east Pacific. Repts. Swedish Deep-Sea Exped. 1947, 48, $(5-1), 1$.

Cook, H. E. and Zemmels, I., 1972. X-ray mineralogy studies - Leg 9. In Hays, J. D. et al., 1972, Initial Reports of the Deep Sea Drilling Project, Volume IX. Washington (U.S. Government Printing Office), 707.
Hays, J.D., Cook, H. E., Jenkins, D. G., Goll, R., Milow, E. D. and Orr, W., 1972. Site 84. In Hays, J. D. et al., 1972, Initial Reports of the Deep Sea Drilling Project, Volume IX. Washington (U.S. Government Printing Office), 615 .

Hays, J. D., Saito, T., Opdyke, J. D. and Burkle, K. H., 1969. Pliocene-Pleistocene sediments of the equatorial Pacific: their paleomagnetic, biostratigraphic, and climatic record. Bull. Geol. Soc. Am. 80, (8), 1481.

Heath, G. R., 1969. Carbonate sedimentation in the abyssal equatorial Pacific during the past 50 million years. Bull. Geol. Soc. Am. 80(4), 689.

Holden, J. C. and Dietz, R. S., 1972. Galapagos gore, Nazcapac triple junction and Carnegie/Cocos Ridges. Nature. 235, 266.

Kowsmann, R., 1973. Regional distribution of coarse components in sediments of the Panama Basin. M.S. Thesis, School of Oceanography, Oregon State University.

Malfait, B. T. and Dinkelman, M. G., 1972. CircumCaribbean tectonic and igneous activity and the evolution of the Caribbean plate. Bull. Geol. Soc. Am. 83(2), 251.

Moore, T. C., Jr., 1972. DSDP: successes, failures, proposals. Geotimes, 17(7), 27. 
Moore, T. C., Jr., Heath, G. R. and Kowsmann, R. O., in press. Biogenic sedimentation in the Panama Basin. Sedimentology.

Morgan, W. J., 1971. Convection plumes in the lower mantle. Nature. 230, 42.

van Andel, $\mathrm{Tj}$. H., 1972. Establishing the age of the oceanic basement. Comm. Earth Sci.: Geophys. 2(6). van Andel, Tj. H. and Heath, G. R., 1970. Tectonics of the Mid-Atlantic Ridge, $6-8^{\circ}$ south latitude. Marine Geophys. Res. 1, 5 .

van Andel, Tj. H., Heath, G. R., Malfait, B. T., Heinrichs, D. F. and Ewing, J. I., 1971. Tectonics of the Panama Basin, eastern equatorial Pacific. Bull. Geol. Soc. Am. 82(6), 1489. 